DOI https://doi.org/10.18551/rjoas.2017-01.22

\title{
THE ROLE OF TENURE AS A MEDIATING FACTOR ON THE EFFECT OF MORAL PERSON AND MORAL MANAGER TOWARD AFFECTIVE COMMITMENT OF EMPLOYEES: A STUDY ON CIVIL SERVANTS OF THE GOVERNMENT OF MALANG REGENCY
}

\author{
Aryati Ana Sofia*, Sudiro Ahmad, Hadiwidjaja Djumilah, Noermijati \\ Faculty of Economics and Business, University of Brawijaya, Indonesia \\ *E-mail: anasofia aryati@yahoo.com
}

\begin{abstract}
The purpose of this study was to examine the role of tenure to strengthen moral person and managers toward affective commitment of employees in organizations in the government institutions of Malang Regency, Indonesia. The research was conducted including the civil servants as many as 55 people. The results of the study analyzed using multiple regression analysis showed that moral person had a significant positive effect on affective commitment, whereas moral manager had no significant effect on affective commitment, and the tenure did not moderate (neither strengthen nor weaken) the effect of moral person and moral manager toward affective commitment of employees.
\end{abstract}

\section{KEY WORDS}

Moral person, moral manager, affective commitment, tenure.

In organizations, particularly government institutions, leaders and employees determine the implementation of good governance for the system to work well. The attitude of the leader will affect the behavior of subordinates. Attitude is one of the three dimensions of moral apart from values and integrity (Trevino et al., 2000). Moral and its three dimensions become important; leaders are said to be good when they practice the three dimensions of moral, i.e. of attitudes, values and integrity.

Aspect of ethics or moral in character of a leader is emphasized in several leadership theories today. The ethical aspects of these leaders are determined by their personal integrity as in some forms of leadership, among others, authentic leadership, ethical leadership, service leadership, spiritual leadership, transformational leadership, and virtual leadership (Cameron, 2011; Cropanzano \& Walumbwa, 2010). Ethical leadership will affect the outcome of employees. Referring to the opinion and Kroeck Sims (1994, in Schwepker, 2001) that ethical leadership contributes to the workers' commitment and satisfaction.

Meyer and Allen (1991) define organizational commitment as a psychological construct that describes the relationship of members of the organization with the organization and it has implications for an individual's decision to continue membership in the organization. Shadur, Kinzle, and Rodwell (1999) explain that employees who are committed to working unit show strong recognition and involvement of employees in the working unit, expressed as follows: "Organizational commitment is defined as the strength of an individual's identification with and involvement in a particular organization." Employees who have a commitment to the organization are likely to remain loyal than in employees who are not committed.

One of the most important factors affecting the commitment is the behavior of a leader or manager (Webb, 2011). Avolio et al. (2004) and Bass and Avolio (1990) also state that commitment is influenced by the style of leadership in the organization. Further, it is noted that leaders with moral dimension will be more influential in guiding employees as leaders can influence and lead workers. However, leaders who are unethical and dishonest will have difficulty in maintaining their employees (Brown and Mitchell, 2010; Toor and Ofori, 2009; Ulrich et al., 2007). Employees can follow the leader or the organization with the help of ethical behavior, as this will impress employees and creates a feeling of confidence to work in fair environment (Schwepker, 2001). 
Ethical leadership is strongly associated with moral; Trevino et al. (2000) reveal that the reputation for ethical leadership rests on two important pillars: the perception on moral leader and the action of leaders as moral manager. Leaders as a moral person are characterized by the properties of individual leaders such as honesty and integrity, while moral manager is the role of a leader to create a strong ethical message to get the attention of subordinates and to influence their thinking and behavior. The second pillar is very important for the formation of ethical leadership. For a leader to be regarded as ethical, it is not enough to be individuals who are ethical, but leaders should also able to find ways for the organization to focus on ethics and values that populate the organization with principles as direction for the behavior of subordinates.

Previous studies analyzing the effect of ethical leadership on organizational commitment has been made by several researchers including a positive relationship between ethical leadership with the behavior of subordinates such as job satisfaction and affective commitment (Brown et al., 2005; Neubert et al., 2009; Ruiz Palomino et al., 2011). Sutherland (2010) also reveals that ethical leadership has significant positive effect on two forms of organizational commitment, i.e. normative and affective commitment.

Based on previous research, this study aims to analyze and examine the influence of the moral person and moral manager on employees' affective commitment. Studies on the influence of moral person and moral manager toward organizational commitment in Indonesia with a focus on affective commitment, especially for public organizations are relatively small. Prottas (2013) reveals that research on the relationship between moral leadership and workers' outcome are relatively few.

In addition, the study also aims to examine the role of tenure in moderating the effect of moral person on affective commitment. Tenure, according to the results of research conducted by Angle and Perry (1981), is positively and directly correlated with organizational commitment. Based on this, the emotional involvement of individuals in the organization in which they work can be seen from their tenure in the organization. Shorter tenure affect the power level of emotional bonding to the organization, as well as social relatively fragile engagement into the organization; otherwise longer tenure brings effect on increasing commitment and smaller possibility to leave the organization. Referring to this, the affective commitment, which indicates emotional attachment of an employee to an organization, is lower for those with shorter tenure. Longer tenure is expected to strengthen the influence of moral person and moral manager on the level affective commitment of employees.

\section{LITERATURE REVIEW}

Moral Person. Moral person as the substance of ethical leadership is becoming an important prerequisite in developing a reputation for ethical leadership as it is associated with the properties, behavior, and decisions made by leaders in the organization. Leaders as a moral person are characterized in terms of individual traits such as honesty and integrity. Moral person is one dimension of ethical leadership that shows the influence of personal characteristics on ethical performance, whether in the trait, value, and integrity. First, a leader's character affects the ethical performance, according to Yukl (2006) the behavioral characteristics of ethical leaders, among others are: 1) humble; 2) emphasizing goodness; 3) honest; 4) full commitment; 5) fair; and 6) responsible. The qualities of a leader relates to the credibility, consistency, and the ability of a leader (Kouzes \& Posner, 1992).

Second, the value of ethics is the basis of the relationship between leaders and subordinates that lead to a mutually agreed form of behavior to achieve the objectives of the organization. Third, integrity shows honesty, willingness to learn from mistakes, consistent in the process of self-development, as well as an example for subordinates.

Moral person as disclosed by Brown (2005) is an aspect that shows of ethical leadership showing the perception on the attitude, character, and altruistic motivation of the leader personally. Piccolo (2010) adds that moral person is a component of ethical leadership that illustrates the nature of moral leader. Thus, based on the statement, it can be 
said that moral person is able to demonstrate the level of leadership traits, behavior, and ethical values held by the leaders in decision-making.

Moral manager. Being an ethical leader does not mean simply being an ethical person. Ethical leaders must also find a way to focus the organization's attention on ethics and values to infuse the organization with the principles that will guide the actions of all employees. Moral manager illustrates that ethical leaders serve as role models for subordinates to uphold ethical standards, to apply penalties and rewards as well as to communicate the importance of ethics for workers. Moral leadership manager describes the ability of a leader in providing role models of ethical behavior for subordinates, explaining and being able to regulate the ethical principles and always considering the ethical element in decision-making.

Tenure. Tenure is an individual experience that will determine the growth in employment and occupation. According to Seniati (2006), tenure is a component consisting of age, length of employment, and position, so, tenure is a time limit to use an employee to contribute their labor to the company so that it will produce working attitude and quality work.

Tenure relates to how long someone works in the organization. Sufficient tenure indicates extensive experience of someone in the organization. Time forms one's experience, knowledge, and skills. Work experience forms one's skills and attitude, such as efficiency and effectiveness in doing the job, ability to analyze and overcome the difficulties and challenges faced, and so forth.

Affective Commitment. Organizational commitment as expressed by Porter (1974) in Schwepker (2001) has a role as a 'psychological bond' for workers that can influence behavior in accordance with the interests of the organization. Thus, the degree of commitment of individual employees is instrumental in the organization's success in achieving the goals and becomes the strength for the organization in the competition. Employee commitment to the organization shows strong recognition and involvement of individuals in the organization.

Mayer and Allen (1991) divide the organizational commitment to 3 key dimensions namely: continuance, normative, and affective commitment. Dimension of affective commitment is the most powerful of the three types and is associated with positive emotional connection to the organization (Pentareddy and Suganthi, 2015). According to Allen and Mayer, employees who have high affective commitment are best in perception and individual characteristics that affect the work (Williamson et al., 2009). Affective commitment is also described as being more influential and can interpret the overall commitment.

According to Meyer and Allen (1993), affective commitment is an emotional bond that is owned by a worker to recognize and increase the sense of involvement in the organization (Pentareddy, Suganthi, 2015). A feeling of belonging, pride, and loyalty to the organization marks high levels of affective commitment. When employees have good commitment, they tend to identify the organization (ownership of the organization), tend to be more actively involved in the work environment and the increasing involvement of an employee in the organization can improve the outcomes of organizational goals (Allen and Meyer, 1990).

Perceptions of ethical leaders will be a positive influence on the decision-making by employees, pro-social behavior, job satisfaction, motivation, and organizational commitment as well as the negative effect on employees' counterproductive behavior (Brown, 2005). Watson (2010) also reveales perception on the value of ethical leaders with have potential impact on the level of organizational commitment of employees. Referring to Brown and Mitchell (2010), Toor and Ofori, (2009), Ulrich et al. (2007) reveal unethical leader will have difficulty in maintaining employees. Therefore, in other words, the characteristics or moral person and moral manager of a leader will influence the level of emotional or affective commitment of employees who indicate the level of involvement of individuals in the organization.

Tenure also affects the affective commitment of employees, as expressed by Angle and Perry (1981) that the employees' age and tenure correlates positively to organizational commitment. Additionally, Allen and Meyer (1991) state that tenure is one of the demographic characteristics alleged to have correlation with organizational commitment. 


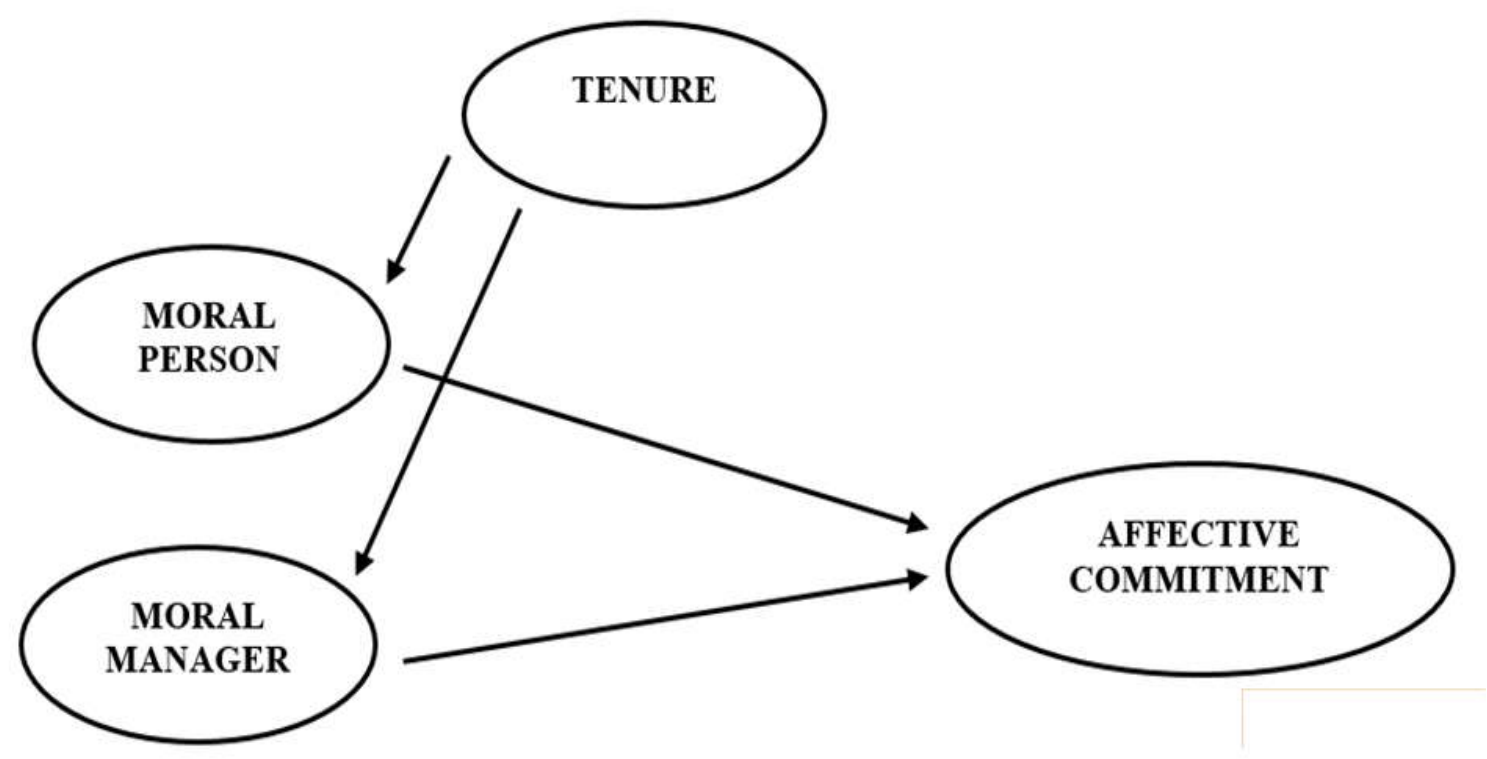

Figure 1 - Conceptual Framework

Each variable, indicator, and item in this study can be seen in the following table:

Table 1 - Variable, Indicators, and Research Items

\begin{tabular}{|l|l|l|}
\hline \multicolumn{1}{|c|}{ Variable } & \multicolumn{1}{|c|}{ Indicator } & \multicolumn{1}{c|}{ Item } \\
\hline $\begin{array}{l}\text { Moral Person (Brown et al, } \\
\text { 2005) }\end{array}$ & $\begin{array}{l}\text { Characteristics } \\
\text { Behavior } \\
\text { Decision making }\end{array}$ & $\begin{array}{l}\text { Honest and trustworthy } \\
\text { Care toward employees' interests } \\
\text { Give examples on how to do things correctly } \\
\text { Care toward employees' thought and ideas } \\
\text { Ethical behavior in daily live } \\
\text { Fair decision-making }\end{array}$ \\
\hline $\begin{array}{l}\text { Moral manager (Brown et } \\
\text { al, 2005) }\end{array}$ & $\begin{array}{l}\text { Communicate ethics and values } \\
\text { Reward and punishment } \\
\text { Role model }\end{array}$ & $\begin{array}{l}\text { Punish employees who break rules } \\
\text { Reward employees who comply with rules } \\
\text { Pay attention to code of ethics } \\
\text { Be a role model for employees }\end{array}$ \\
\hline Tenure (Noermijati, 2015) & $\begin{array}{l}\text { Short } \\
\text { Long }\end{array}$ & $\begin{array}{l}\text { Less than 5 years } \\
\text { More than 5 years }\end{array}$ \\
\hline $\begin{array}{l}\text { Affective commitment (Allen } \\
\text { and Mayer, 1991) }\end{array}$ & $\begin{array}{l}\text { Feel emotional bond } \\
\text { Feel happy to be with the organization } \\
\text { Feel as part of the organization } \\
\text { Feel to be engaged to the organization } \\
\text { Identification } \\
\text { Engagement }\end{array}$ & $\begin{array}{l}\text { Feel that organizational problems are } \\
\text { employees' problems }\end{array}$ \\
\hline
\end{tabular}

\section{RESEARCH METHODS}

The research was conducted at functional groups of civil servants of Malang Regency Government, specifically on Department of Technical and Regional Secretariat. Sampling in this study refers to Roscoe (1975) in Sekaran (2003), by multiplying the number of indicators with a minimum of 5 times, with 11 indicators, and the number of samples obtained in this study was 55 people. The questionnaire consisted of 18 statements, comprised of 11 on moral person and manager developed on a scale of ethical leadership (Brown, 2005). Measurement of affective commitment is developed from Alen and Meyer (1993) as many as 5 items, while the 2 items on tenure were adopted from Noermijati (2015), consisting of short and long tenure. Furthermore, the data were analyzed using regression analysis to the role of moderation. 


\section{FINDINGS AND DISCUSSION}

The majority of respondents were female $(56.3 \%)$ in the productive age between $31-40$ years $(45 \%)$, and as many as $98.2 \%$ were Muslim. Most of them graduated from Bachelor Degree $1(69.1 \%)$. As many as $87.3 \%$ of respondents were married. The model was valid and reliable. The indicators were valid with a significance level of $<0.05$ and the reliability test showed that the Cronbach Alpha value was $>0.6$. In this study, the moderation regression was used to describe whether tenure moderated influence of moral person and moral manager on the affective commitment.

Table 2 - The Results of Moderation Regression Analysis

\begin{tabular}{|l|l|l|}
\hline \multicolumn{1}{|c|}{$\mathrm{n} / \mathrm{n}$} & Path Coefficient & Sig \\
\hline Moral Person (X1) & 0.338 & 0.003 \\
\hline Moral manager (X2) & 0.092 & 0.241 \\
\hline X1 x Tenure & 0.208 & 0.051 \\
\hline X2 x Tenure & 0.072 & 0.294 \\
\hline \multicolumn{2}{|c|}{0.274} \\
\hline
\end{tabular}

As the above table shows, the value of $\mathrm{R}$ square is 0274 , meaning that the regression model can explain how tenure moderates the effect of moral person and moral manager of the affective commitment, as much as $27.4 \%$, while the rest $72.6 \%$ is explained by other variables outside variables used in this study.

The Effect of Moral Person on Affective Commitment. Based on the above table, it can be seen that the relationship of moral person and affective commitment has a path coefficient value of 0.338 with a significance value of 0.003 . As the significance value of $<0.01$, it can be said that moral person has significant positive effect on affective commitment.

The Effect of Moral Manager on Affective Commitment. Based on the above table, it can be seen that the relationship of moral manager and affective commitment has a path coefficient value of 0.092 with a significance value of 0.241 . As the significance value of < 0.01 , it can be said that moral manager has significant positive effect on affective commitment.

Tenure as a Moderating Variable on the Effect of Moral Person and Moral Manager toward Affective Commitment. The path coefficient of tenure moderation on the relationship between moral person and affective commitment was 0.208 with a significance value of 0.05 which means tenure moderates the effect of the moral person on affective commitment, . However, the value of the coefficient path after moderation is smaller than the direct effect, it can be said that tenure weakens effect of moral person toward affective commitment. In the relationship between moral manager and affective commitment, tenure does not moderate effect of moral manager on affective commitment.

The research model can be described as seen from Figure 2.

The cross loading values of each item indicate that based on the assessment of respondents' perception, decision-making indicator shown through fairness becomes a good predictor of the perception of respondents regarding the moral person. Employees' perceptions on the moral manager of leaders of Malang Regency Government are best predicted by the leadership role in communicating ethics and values within the organization, while the emotional bond of employees, who are happy to build their career in the organization, reflects perception on affective commitment.

Based on the analysis above, it can be seen that affective commitment of employees is affected by the perception of employees to moral person, which is the characteristics of leaders, behavior, and ethical decision-making by leaders. Leaders perceived as capable of providing exemplary in characteristics, and ethical decision-making behavior can affect the level of affective commitment, which reflects the emotional bond of employees with the institution where they work. This fact supports Brown (2006) which states that ethical leadership is directly related to the attitude of the work of subordinates, and he argues that ethical leadership creates organizational commitment of subordinates. 


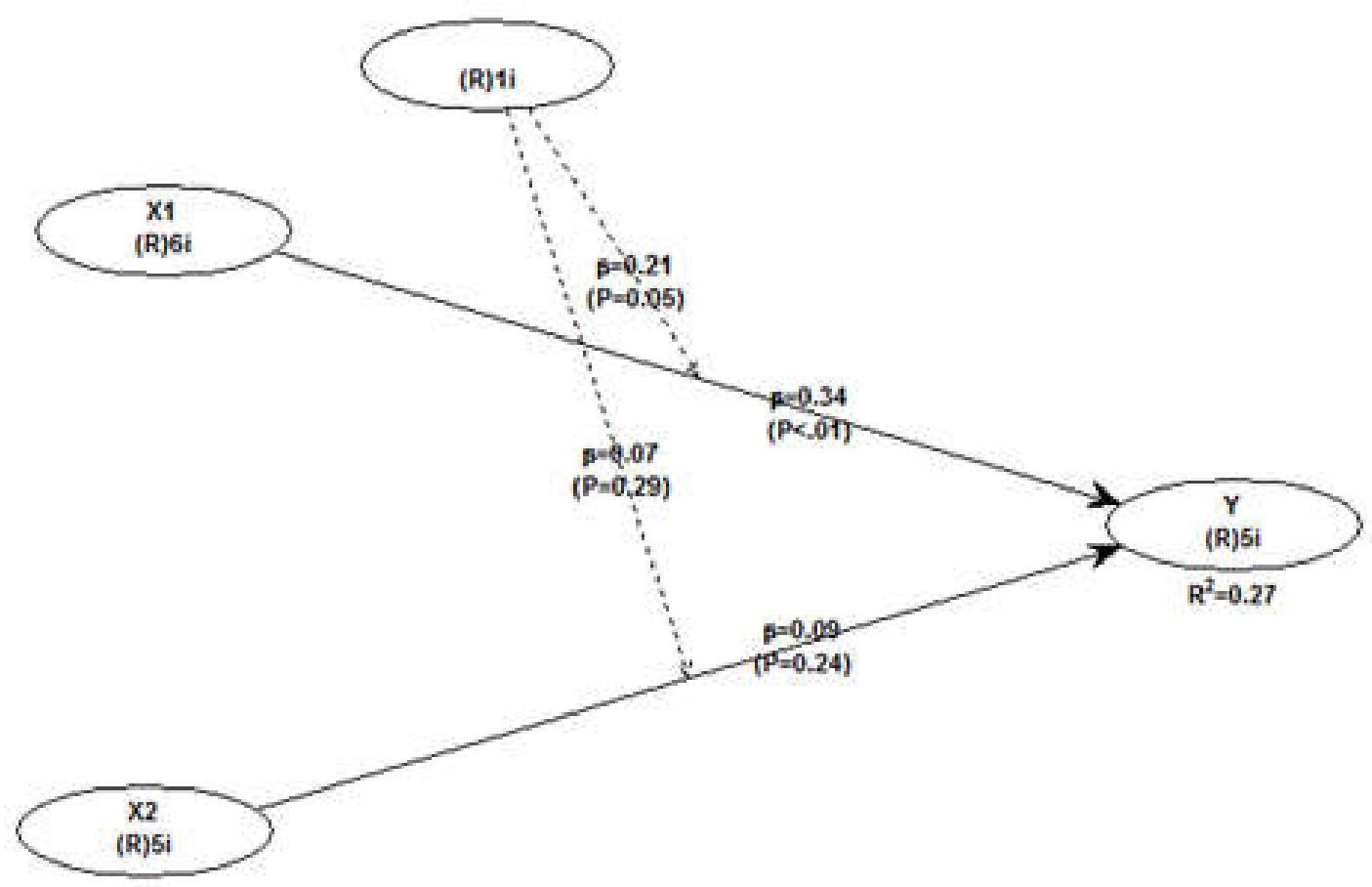

Figure 2 - Research Model

The results of this study are consistent with the results of Ruiz et al. (2011) which states ethical leadership of supervisor influence directly and significantly related to affective commitment. Neubert (2009) argues that the behavior of ethical leadership creates a strong atmosphere for the entire organization, especially to stimulate job satisfaction and affective commitment.

The study also supports research Kim and Brymer (2011) that ethical leadership shown by superiors in a manner that is fair, caring, open, sincere, and truthful, play an important role in increasing job satisfaction of subordinates, including their satisfaction with working conditions and salaries. Further, it is also disclosed that the behavior of leaders also lead to affective commitment to the organization such as proud of the organization, concerned about the future of the organization, and sharing the same values with the organization. However, the results are not in line with the research by Den Hartog and De Hoogh (2009), which examines the behavior of ethical leadership reflected on the honesty, integrity, and behavior empowering organizational commitment. Fair, honest, and trustworthy leaders who also empower employees are associated with affective and normative commitment; honest and fair leaders have more powerful effect on normative commitment than on affective commitment.

Moral manager may have no significant effect against affective commitment, as perception of subordinate to moral manager to the application of discipline on employees who violate the rules of the organization is weak. It supports research by Karrasch (2005) that organizational commitment has been found to be a predictor of the ability of leadership. High level of affective and normative commitment becomes the predictor on the evaluation of high leadership, but sustainable commitment is predictor of weak evaluation of leadership. This may reflect that affective commitment is a stronger predictor of the behavior of the leader than normative commitment. Based on the results, evaluation of the leader on the employees indicated on the application of weak disciplined level causes moral manager to be not influential toward affective commitment.

Based on these results, the role of tenure moderation is to weaken the influence of moral person on affective commitment. These results concur with those of Meyer et al. (2002) that age and tenure has a positive effect but is very weak related to the three 
components of organizational commitment, i.e. affective, normative, and continuance commitment.

The level of affective commitment of employees, which describe the sense of belonging and emotional involvement of employees with the organization they work, is influenced by the moral leadership reflected in the characteristics, behavior, or fairness in decision-making, and is weakened by tenure. In other words, the longer employees work, leaders no longer become a factor helping them to build strong relationship with the organization. In fact, as employees are moved from one institution to another, emotional bond does no longer depend on how leaders behave and apply ethical principles in the organization

\section{CONCLUSION AND RECOMMENDATIONS}

It has been proven that moral person affects affective commitment of employees, but moral manager has no effect on affective commitment. In addition, tenure weakens the influence of moral person on affective commitment, and tenure does not moderate the effect of moral manager toward affective commitment of employees.

Future researchers are suggested to balance the proportion of employees with long and short tenure to explain the moderating influence of tenure more comprehensively. Practitioners are suggested to improve the role of leaders in practicing ethical leadership reflected in the moral person and moral manager to improve employee emotional attachment to the institution.

\section{REFERENCES}

1. Allen, N. J., \& Mayer, J. P. (1990). The Measurement and Antecedent of Affective, Continuance, and Normative Commitment to Organization. Journal of Occupational Psychology Vol. 63, 1 - 18.

2. Allen, N.J., \& Mayer, J. P. (1991). A Three Component Conceptualization of Organizational Commitment. Human Resource Management, review 1, 61-98.

3. Angle, $\mathrm{H}$ and Perry, J. (1981). An Empirical Assessment of Organizational Commitment and Organizational Effectiveness. Administrative Science Quarterly, 26(1):1-14.

4. Avolio, B.J., Zhu, W., Koh, W., Bhatia, P. (2004). Transformational Leadership and Organizational Commitment: Mediating role of Psychological Empowerment and Moderating Role of Structural Distance. Journal of Organizational Behaviour. 25. pp: 951968.

5. Bass, B.M., Avolio, B.J. (1990). The Implication of Transactional and Transformational Leadership for Individual, Team and Organizational Development, 4. 231-272.

6. Brown, M.E., Mitchell, M.S (2010). Ethical and Unethical Leadership: Exploring New Avenues for Future Research. Business Ethics Quarterly, 20(4): 583-616.

7. Brown, Michael; Trevino, Linda; Harrison, David A. (2005). Ethical Leadership: A Social learning perspective for Construct Development and Testing. Organizational Behavior and Human Decision Processes 97: 117-134.

8. Cameron, K.S. (2011). Effects of Virtous Leadership on Organizational Performance. In S.I.Donaldson, M. Csikszentmihalyi, J. Nakamura, S.I. Donaldson, M. Csikszentmihalyi, J. Nakamura, S.I. Donaldson, M. Csikszentmihalyi, \& J. Nakamura (Eds), Applied Positive psychology: Improving everyday life, health, schools, work, \& society (pp.171183). New York, Routledge/Taylor \& Francis.

9. Cropanzano, R., Walumbwa, F.O. (2010). Moral leadership: A short primer on competing Perspective. In Marshall Schminke (ed.), Managerial Ethics: Managing the Psychology of Morality. Routledge 21--52 (2010).

10. Kim and Brymer. (2011). The Effects of Ethical Leadership Manager, Job Satisfaction, Commitment, Behavioral Outcomes and Firm Performance. International Journal of Hospitality management, pp 1020-1026.

11. Meyer, J.P., and Allen, M.J.(1991). A Three Component Conceptualization of Organizational Commitment. Human Resource Management Review, 1(1): 61-89. 
12. Meyer, J.P., Stanley, D.J. Herscovitch, L Topolnytsky, L. (2002). Affective, Continuance and Normative Commitmenr to the Organization: A Meta-Analysis of antecedents, Correlates, and Consequences. Journal of Vocational Behavior, pp 20-52.

13. Mowday, R.T., Steers, R.M., Porter L.W. (1979). The Measurement of Organizational Commitment. Journal of Vocational Behavior. Vol. 14.224-247

14. Neubert, M.J., Carlson, D.S., Kackmar, K.M., Robert, J.A., Chonko, L.B. (2009). The Virtous influence of Ethical Leadership Behavior: Evidence from the Field. Journal of Business Ethics, 90(2), 157-170.

15. Neubert, M.J., Wu, C., Roberts, J.A. (2013). The Influence of Ethical Leadership and Regulatory Focus on Employee Outcomes. Business Ethics Quarterly, Education and Development Studies, 1 (3).

16. Noermijati. (2015) Peran kepemimpinan transforasional dan motivasi terhadap kinerja karyawan dengan moderasi masa kerja. Jurnal keuangan dan perbankan 19(2), 326-335

17. Piccolo, R.F., Greenbaum, R.L., Eissa, G. (2010). Ethical Leadership and Core Job Characteristics; Designing Jobs for Employee Well Being. Journal of Organizational Behavior, Vol. 31. pp: 259-278.

18. Prottas, D.J. (2013). Relationship among employee Perception of Their Manager's Behavioral Integrity, Moral Distress, and Employee Attitudes and well-Being. J. Bus Ethics. 113: 51-60.

19. Ruiz, P., Ruiz, C., Martinez, R. (2010). Improving the "Leader-Follower" Relationship: Top Manager or Supervisor? The Ethical Leadership Trickle Down Effect on Follower Job Response. Journal of Business Ethics. 99: 587-608.

20. Schwepker, C.H. (2001). Ethical climate's relationship to Job Satisfaction, Organizational Commitment, and Turnover intention in the sales force. Journal of Business Research. 54: 39-52.

21. Seniati. (2001). Hubungan Antara Persepsi dan Diskrepansi Harapan-Persepsi Karyawan Atas Pengololaan SDM dalam Organisasi dengan Komitmen Karyawan pada Organisasi. Journal Seri Sosial dan Humaniora, Vol.5 No.1. Seniati, L. (2006). Pengaruh Masa Kerja, Trait Kepribadian, Kepuasan Kerja, dan Iklim Psikologis terhadap Komitmen Dosen pada Universitas Indonesia. Makara, Sosial Humaniora. Vol. 10 , 88-97.

22. Sekaran, U. (2003). Research Method For Business: A Skill Building Approach, 4th Edition, New York: John Willey and Sons, Inc.

23. Shadur, M.A., Kinzle, R., and Rodwell, J.J. (1999). The Relations between Organization Climate and Employee Perceptions of Involvement. Group \& Organization Management, Vol. 24, Iss. 4, p 479-504

24. Sutherland, M.A. (2010). An Examination of Ethical Leadership and Organizational Commitment. Unpublished Dissertation Doctor of Bushiness Administration. Nova Southeastern University

25. Toor, S., Ofori, G. (2009). Ethical Leadership: Examining the Relationship with full Range Leadership Model, Employee Outcomes, and Organizational Culture. Journal of Business Ethics. 90 (4); 533-547.

26. Trevino, L.K., Hartman, L.P, Brown, M. (2000). Moral Person and Motral Manager. How Executives Develop a reputation for Ethical Leadership. California Management Review, 42. 128-142.

27. Watson, T. (2010). Leader Ethics and Organizational Commitment. Paper Presentation at the Mid-Atlantic Leadership Scholars Forum.

28. Webb, K.S. (2011). Emotional Intelligence and worker Commitment: The Impact of leaders' Behavior on Employee Commitment to Their Supervisor and the organization. Advancement of Management and International Business Conference Proceedings.

29. Yukl, G. (2006). Leadership in Organization $\left(6^{\text {th }}\right.$ Edition). Upper Saddler River, NJ: Prentice Hall.

30. Zhu, W., May, D.R., Avolio, B.J. (2004). The Impact of Ethical Leadership Behavior on Employee Outcomes: The Roles of Psychological Empowerment and Authenticity. Journal of Leadership \& Organizational Studies Summer 11. 16-26. 